\title{
Marketing of Imported Agricultural Products and Its Effects on Producers and some Hinterlands (UPN) Households in the City of Kinshasa/RDC from 2012 to 2018
}

\author{
Marcel Bwama Meyi ${ }^{1}$, Sylvestre Ruremesha ${ }^{2}$, Maseka W. ${ }^{3}$, Grégoire Mashala \\ Bitwakamba ${ }^{4}$ and Romeo Ciminello ${ }^{5}$
}

\begin{abstract}
Our goal was to understand the behavior of sellers and consumers of imported agricultural products (corn, rice, chicken and pork) vis-à-vis local products. To test our hypotheses, we used methods of analysis and surveys using documentary techniques and the interview. The results reveal that $4.4 \%$ of respondents say they buy imported rice because it is cheaper and is found in abundance; $22.4 \%$ say it is of better quality and $6.9 \%$ say it is in good taste. This confirms our first hypothesis. Our analysis shows that $70.7 \%$ of respondents believe that local cereals are of better quality and $29.3 \%$ of respondents believe that imported cereals are not better. 58.6\% of respondents prefer imported fresh food; $39.9 \%$ prefer local fresh food and $1.7 \%$ did not give their opinion. The vast majority, $86.2 \%$ of the respondents, want local products to be sold by the producers themselves, $5.2 \%$ want it to be a farm product and $3.4 \%$ to have a local brand. These results support the sustainable economy in the community. However, $22.4 \%$ of respondents complain of being exposed to cholesterol which can lead to cardiovascular diseases in the short and long term following consumption of live spawns without prior checks of health and public health officials; on the other hand $77.6 \%$ are abstraction, following the precariousness of life and poverty in Kinshasa. At the national level, taking into account the agricultural sector is inevitable for sustainable development. The state must take responsibility by feeding its own population with organic products of good quality. So, we must work and invest in the agricultural sector in the DRC, to reduce the food and economic dependence that the country is going through. The tax policy on imported fresh food would be one way to support local production and reduce imports so much that makes the balance of trade deficit in the DRC.
\end{abstract}

Keywords: Marketing, imported agricultural products, Hinterlands households, Kinshasa, DRC

\section{Introduction}

With an area of 2,345,095km2 $3.3 \%$ in water, 80 million hectares of arable land, 145 million hectares of forest, a subsoil very rich in mineral resources, significant water potential $(52 \%)$, fresh water resources of the continent and energy (more than 100,000 MW), a climate favorable to agriculture and an estimated population of more than 80 million inhabitants, the Democratic Republic of Congo (DRC) has an important potential for economic growth and human development that has not been exploited so far (MinPlan, 2017).

It still ranks among the least developed countries despite the macroeconomic progress it has made since 2002. More than half of its population is still affected by poverty despite the fact that the implementation of the Millennium Development Goals for

\author{
${ }^{1} \mathrm{UPN}$ \\ 2UNIGOMA \\ ${ }^{4} \mathrm{U} . \mathrm{KA}$ \\ ${ }^{5}$ Hermes
}


Development (MDG). This country lives in a context of recurring wars, epidemics (EBOLA) in the East and instability of political institutions that do not favor the take-off of economic growth and development (MinPlan, 2018).

And yet, the soil of Kinshasa is arenoferrasol type, consisting of fine sands with a clay content generally less than $20 \%$. They are characterized by a low organic matter content and a low saturation of the absorbent complex. As for the subsoil, bread notes that it is characterized by a Precambrian basement, which includes red sandstone rocks finely stratified and often spathic foot.

It should be noted that the initial vegetation, in several areas of Kinshasa, consisted of gallery forests on the one hand and grassland formations on the other hand the gallery forests along the main rivers, being in the humid valleys and of the Guinian rain type. Congolese, are only pre-forest fallows heavily degraded, intensively exploited and come in the form of forest recruits of various ages not elsewhere, a small group typically ruderal vegetation runs along the rails of the railway on a strip of a few meters of widths (MAXIMY R, 1984).

Overall, field observations reveal the Kinshasa region hosts different types of vegetation; forest, grassland, ruderal and aquatic each type of vegetation being linked to a number of ecological parameters. Given such a description, we conducted this research to know the share of the marketing of imported agricultural products and its effects on the producers and some households Hinterlands (UPN) of the city of Kinshasa From 2012 to 2018. More precisely in the district Ngumba Kikusa.

This research questions In terms of trade, how are imported and local agricultural products appreciated by consumers? Where do these products come from? What would be the effects on consumers, local producers, local market and producer income? What strategies need to be implemented to improve local production, the market and ensure food sovereignty?

In the face of such an interrogation, we believe that imported agricultural products would be appreciated by the consumers by their prices, availabilities and less rated because of the taste and certain diseases for which they are responsible; on the other hand, it would hurt local producers; Finally, many of these products would come from foreign countries (Europeans, Asians and Africans).

For the methodology used (BRUNO A., 1973, surveys and documentation were used as research methods; with emphasis on interviewing techniques using a survey and observation questionnaire (GRAWITZ, D. 2011).

\section{Results}

\subsection{Characteristic of the population surveyed}

Table 1: Distribution of respondents by gender

\begin{tabular}{|c|c|c|c|c|c|}
\hline \multicolumn{2}{|c|}{} & Effectifs & Pourcentage & Pourcentage valide & Pourcentage cumulé \\
\hline \multirow{4}{*}{ Valide } & MASCULIN & 32 & 55,2 & 55,2 & 55,2 \\
\cline { 2 - 6 } & FEMININ & 25 & 43,1 & 43,1 & 98,3 \\
\cline { 2 - 6 } & Sans réponse & 1 & 1,7 & 1,7 & 100,0 \\
\cline { 2 - 6 } & Total & 58 & 100,0 & 100,0 & \\
\hline
\end{tabular}

Source : investigation 2018 
Table 1 shows that $55.2 \%$ of respondents are male, $43.1 \%$ are female and $1.7 \%$ are respondents who did not answer the question. It should be noted that the agricultural production activities are carried out according to the level of studies as in Table 2, below:

Table 2: Distribution of respondents / level of study

\begin{tabular}{|l|l|c|c|c|c|}
\hline \multicolumn{2}{|c|}{} & Level of study & \\
\hline \multirow{5}{*}{} & Effectifs & Pourcentage & $\begin{array}{c}\text { Pourcentage } \\
\text { valide }\end{array}$ & $\begin{array}{c}\text { Pourcentage } \\
\text { cumulé }\end{array}$ \\
\hline \multirow{5}{*}{ Valide } & $\begin{array}{l}\text { SUPERIEUR ET } \\
\text { UNIVERSITAIRE }\end{array}$ & 22 & 37,9 & 37,9 & 37,9 \\
\cline { 2 - 6 } & SECONDAIRE & 21 & 36,2 & 36,2 & 74,1 \\
\cline { 2 - 6 } & PRIMAIRE & 7 & 12,1 & 12,1 & 86,2 \\
\cline { 2 - 6 } & se sont réservées & 4 & 6,9 & 6,9 & 93,1 \\
\cline { 2 - 6 } & AUTRES & 4 & 6,9 & 6,9 & 100,0 \\
\cline { 2 - 6 } & Total & 58 & 100,0 & 100,0 & \\
\hline
\end{tabular}

Source : investigation, 2018

The majority of respondents, $74.1 \%$, are sufficiently educated, that is to say have the higher level and university or secondary level. In decision-making, the training received is a determining factor for the household (UNESCO, 2016). In the DRC, education is still a problem, especially for the girl.

\subsection{Criteria for consumer choice}

The consumption of agricultural products of plant or animal origin in Kinshasa depends on several criteria as shown in Table 3, following:

Table 3: Criteria of choice for purchase of food products

\begin{tabular}{|c|c|c|c|c|c|}
\hline & & Effectifs & Pourcentage & $\begin{array}{c}\text { Pourcentage } \\
\text { valide }\end{array}$ & $\begin{array}{c}\text { Pourcentage } \\
\text { cumulé }\end{array}$ \\
\hline & PRIX & 14 & 24,1 & 24,1 & 24,1 \\
\hline & NOURRISSANT & 12 & 20,7 & 20,7 & 44,8 \\
\hline & $\begin{array}{l}\text { BON POUR LA } \\
\text { SANTE/EQUILIBRE }\end{array}$ & 11 & 19,0 & 19,0 & 63,8 \\
\hline & COUT & 11 & 19,0 & 19,0 & 82,8 \\
\hline & SANS REPONSE & 3 & 5,2 & 5,2 & 87,9 \\
\hline valide & FRAICHEUR & 3 & 5,2 & 5,2 & 93,1 \\
\hline & $\begin{array}{l}\text { CONDITIONNEMENT ET } \\
\text { BONNE CONSERVATION }\end{array}$ & 2 & 3,4 & 3,4 & 96,6 \\
\hline & $\begin{array}{l}\text { FAIRE VIVRE LES } \\
\text { PRODUCTEURS }\end{array}$ & 1 & 1,7 & 1,7 & 98,3 \\
\hline & PRIX, GOUT & 1 & 1,7 & 1,7 & $100 \Omega$ \\
\hline & Total & 58 & 100,0 & 100,0 & 100,0 \\
\hline
\end{tabular}

Source : investigation 2018

Examination of Table 3 shows that among the respondents, 43.1\% are based solely on the price, $39.7 \%$ have the criterion that the products are nutritious, $12 \%$ are based on the fact that the products are good for health and balanced, $5.2 \%$ are based on freshness; 
$3.4 \%$, on packaging and good preservation of products. Consumer behavior is a major psychological factor in a society (VAN VRACEM P and MARTINE JANSSENS, M, 1994).

In front of such a table, only the price remains a dominant factor on this market. The provenance and quality of the product are of the least concern to Kinshasa consumers. This situation justifies how the population consumes more of the products coming from the outside because of the cheaper price rather than those produced locally which would cost a little more expensive, but of good quality.

From an economic point of view, the consumption of goods and services depends on the choice, preference and income of the consumer (IDWIGHT.H et al, 2006). In Kinshasa, consumption is more influenced by the price of a product. Overall, the income of this population living in the hinterlands of Kinshasa city is low (FAO, 2010).

\subsection{Consumer choice in the market}

\subsubsection{Imported and local rice}

The objective is to know how many households consume local rice compared to imported rice in the hinterland of Kinshasa.

Table 4: Consumption of local rice and imported rice

\begin{tabular}{|c|c|c|c|c|c|}
\hline \multicolumn{6}{|c|}{ Buy rice } \\
\hline & & Effectifs & Pourcentage & Pourcentage valide & Pourcentage cumulé \\
\hline \multirow{3}{*}{ Valide } & IMPORTE & 52 & 89,7 & 89,7 & 89,7 \\
\hline & LOCAL & 6 & 10,1 & 10,1 & 100,0 \\
\hline & Total & 58 & 100,0 & 100,0 & \\
\hline
\end{tabular}

Source: logiciel SPSS 20

Table 4 shows that $89.9 \%$ buy imported rice; only $10.1 \%$ opt for local rice. Local rice is too little consumed in Kinshasa as we said before. It is a danger to the economy and the health of the people of a country. This commodity is among the staple foods consumed in Kinshasa (KAKONDE and TOLLENS, 2001).

\subsubsection{Local and imported corn}

Table 5: Domestic and Imported Corn Consumption (Flour)

\section{ACHAT MAÏS}

\begin{tabular}{|l|l|c|c|c|c|}
\hline & Effectifs & Pourcentage & Pourcentage valide & Pourcentage cumulé \\
\hline \multirow{5}{*}{ Valide } & SANS REPONSE & 40 & 69,0 & 69,0 & 69,0 \\
\cline { 2 - 6 } & LOCAL & 15 & 25,9 & 25,9 & 94,8 \\
\cline { 2 - 6 } & IMPORTE & 3 & 5,1 & 5,1 & 100,0 \\
\cline { 2 - 6 } & Total & 58 & 100,0 & 100,0 & \\
\hline
\end{tabular}

logiciel SPSS 20

Table 5 shows that $69 \%$ of the respondents did not comment; $25.9 \%$ say they consume local corn and $5.1 \%$ consume imported maize. Unlike rice, the population of Kinshasa UPN and the hinterlands prefer to consume more local corn than imported. This can be 
justified by several reasons: taste, price, and good quality. For this work, food dependence is a form of economic recolonization of a country (KASONGO N, 2008).

\subsection{Rice and maize consumption}

We can say that this commercial circuit is composed of suppliers (different countries), markets and consumers (GENEREUX J., 2004). However, the DRC is struggling to feed its population (kinoise) in particular and the provinces in general. This situation can be explained by a small budget allocated to the agricultural sector, low investment in this area, etc. the economy of the country is dependent on foreign countries for the food of the population, it is a challenge.

Table 6: Preference des cereales (riz et maïs) en termes de qualite

\begin{tabular}{|c|l|c|c|c|c|}
\hline \multicolumn{7}{|c|}{} & Effectifs & Pourcentage & Pourcentage valide & Pourcentage cumulé \\
\hline \multirow{3}{*}{ Valide } & Local & 41 & 70,7 & 70,7 & 70,7 \\
\cline { 2 - 6 } & Importé & 17 & 29,3 & 29,3 & 100,0 \\
\cline { 2 - 6 } & Total & 58 & 100,0 & 100,0 & \\
\hline
\end{tabular}

Source: investigation, 2018

Table 6 shows that $70.7 \%$ of respondents believe that local cereals are better qualities and $29.3 \%$ of respondents believe that imported cereals are not better, but are cheaper in the market. - local cereals (maize and rice). They are cereals rich in nutrients and easily digestible for health (GIRDD-GRET, 2006).

We can illustrate this by Graph 1, below, which shows that local products taste better and are better qualities than imported.

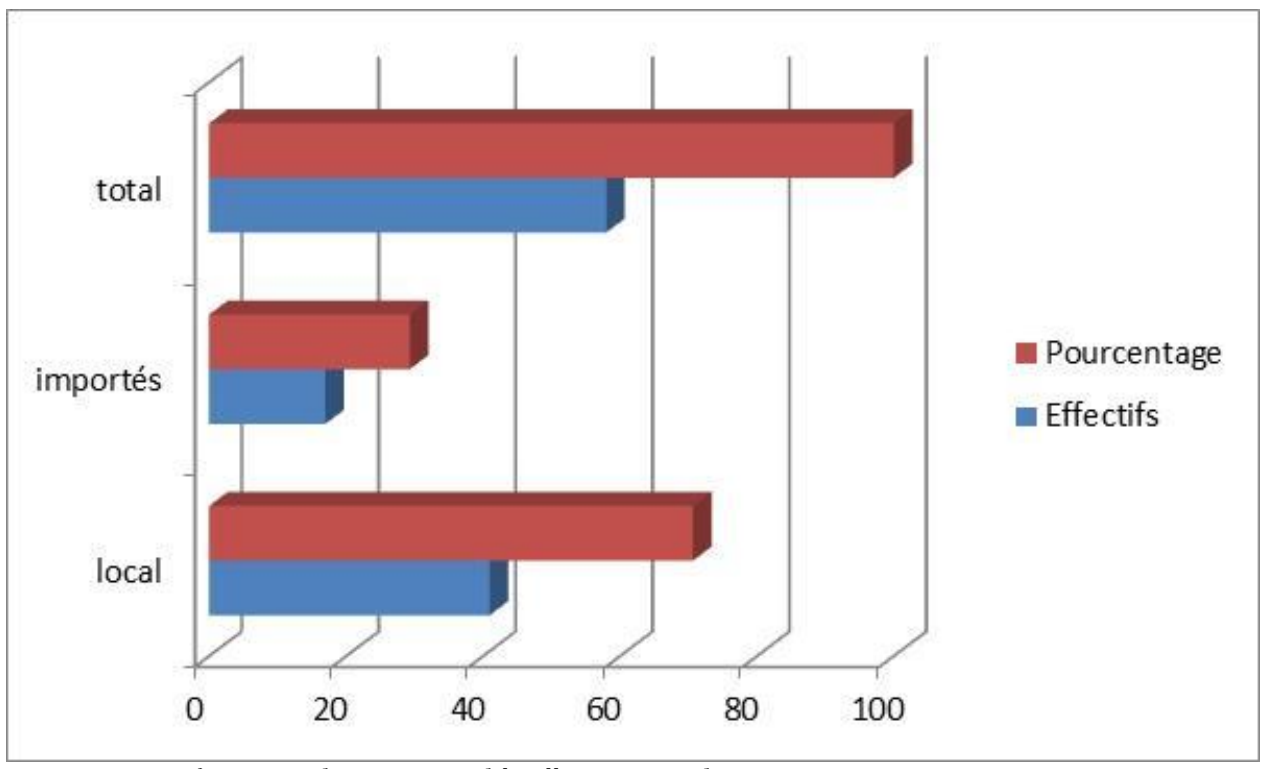

Fig 1: percentage of maize and rice consumed locally or imported 


\subsection{Origin of products}

Indeed, the traceability of imported products (fresh food) is described as follows:

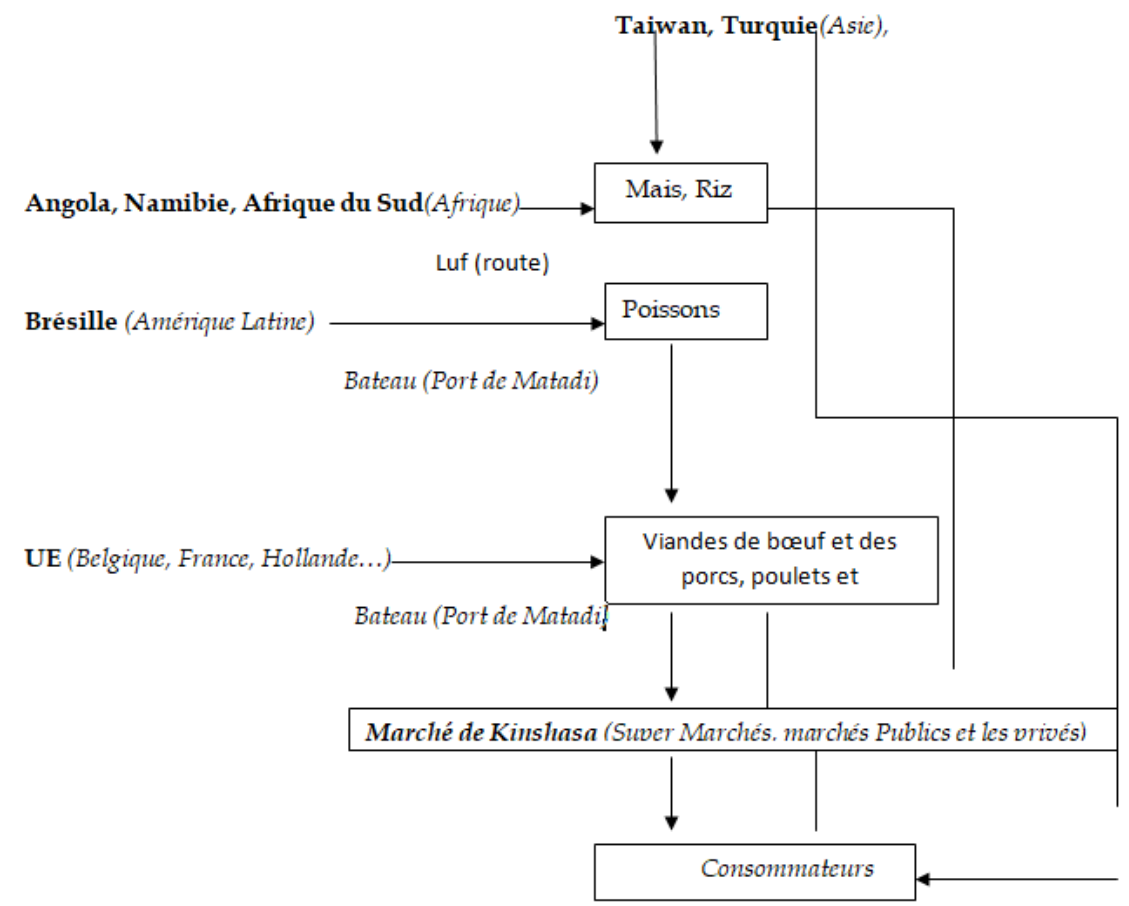

Source: Survey, 2018

It is crucial to promote local production because it is the engine of development and economic growth of a nation (BUBLOT G, 1974).

\subsection{Income of the respondents}

Among consumers, the source of income varies from household to household as shown in Table 6, which follows:

Table 7: Consumer income source

\begin{tabular}{|c|c|c|c|c|c|}
\hline & Origine & Effectifs & Pourcentage & $\begin{array}{l}\text { Pourcentage } \\
\text { valide }\end{array}$ & $\begin{array}{l}\text { Pourcentage } \\
\text { cumulé }\end{array}$ \\
\hline & PETIT COMMERCE & 38 & 65,5 & 65,5 & 65,5 \\
\hline & AUTRE & 9 & 15,5 & 15,5 & 81,0 \\
\hline & $\begin{array}{l}\text { FONCTIONNAIRE DE } \\
\text { L'ETAT }\end{array}$ & 7 & 12,1 & 12,1 & 93,1 \\
\hline Valide & ACTIVITE ARTISANALE & 2 & 3,4 & 3,4 & 96,6 \\
\hline & & 1 & 1,7 & 1,7 & 98,3 \\
\hline & AGRICULTURE & 1 & 1,7 & 1,7 & 100,0 \\
\hline & Total & 58 & 100,0 & 100,0 & \\
\hline
\end{tabular}

logiciel SPSS 20 
Table 7 shows that $65.5 \%$ of the respondents derive their income from small businesses; $12.1 \%$ are civil servants of the State; $3.4 \%$ derive their income from craft activities and $1.7 \%$ from agricultural activities.

Indeed, agricultural activities in Kinshasa, are not a priority as demonstrated by the results obtained $(1.7 \%)$. And the power in place cannot put the consistent means to fight against this food addiction. This situation exposes the country and more particularly the kinois to be dependent from the outside with regard to their consumption in staple food. It is time for this to change to one day build a sustainable economy and ensure food security.

\subsection{Fresh food}

Among the most consumed fresh food in Kinshasa, we have chickens, pigs, fresh fish or ginchar (piodi: vernacular name in lingala), cow meat ... these foods come from outside the country. These foods cause certain diseases in the community because of unsatisfied hygienic conditions, exceeding the date of consumption, poor quality .... Hence control is essential to protect consumers.

Table 8: Choice in quality and conservation of fresh food

\begin{tabular}{|l|l|c|c|c|c|}
\hline & Effectifs & Pourcentage & Pourcentage valide & Pourcentage cumulé \\
\hline \multirow{5}{*}{ Valide } & IMPORTE & 39 & 67,2 & 67,2 & 67,2 \\
\cline { 2 - 6 } & LOCAL & 18 & 31,0 & 31,0 & 98,3 \\
\cline { 2 - 6 } & SANS REPONSE & 1 & 1,7 & 1,7 & 100,0 \\
\cline { 2 - 6 } & Total & 58 & 100,0 & 100,0 & \\
\hline
\end{tabular}

logiciel SPSS 20

Regarding the quality and conservation of fresh food, the majority of respondents, $67.2 \%$, chose fresh food imports, while $31 \%$ opted for local products and $1.7 \%$ have not pronounced.

\subsection{Links between level of education and sex}

Table 9: Links level of study and gender of respondents

\begin{tabular}{|c|c|c|c|c|c|c|}
\hline & \multicolumn{3}{|c|}{ SEXE } & \multirow[b]{2}{*}{ Total } \\
\hline & & & $\begin{array}{c}\text { SANS } \\
\text { REPONSE }\end{array}$ & MASCULIN & FEMININ & \\
\hline \multirow{10}{*}{$\begin{array}{l}\text { NIVEAU } \\
\text { D'ETUDES }\end{array}$} & \multirow{4}{*}{ PRIMAIRE } & Effectif & 1 & 2 & 1 & 4 \\
\hline & & $\%$ compris dans SEXE & $100,0 \%$ & $6,2 \%$ & $4,0 \%$ & $6,9 \%$ \\
\hline & & Effectif & 0 & 2 & 5 & 7 \\
\hline & & $\%$ compris dans SEXE & $0,0 \%$ & $6,2 \%$ & $20,0 \%$ & $12,1 \%$ \\
\hline & \multirow{2}{*}{ SECONDAIRE } & Effectif & 0 & 11 & 10 & 21 \\
\hline & & \% compris dans SEXE & $0,0 \%$ & $34,4 \%$ & $40,0 \%$ & $36,2 \%$ \\
\hline & \multirow{2}{*}{$\begin{array}{l}\text { SUPERIEUR ET } \\
\text { UNIVERSITAIRE }\end{array}$} & Effectif & 0 & 15 & 7 & 22 \\
\hline & & \% compris dans SEXE & $0,0 \%$ & $46,9 \%$ & $28,0 \%$ & $37,9 \%$ \\
\hline & \multirow{2}{*}{ AUTRES } & Effectif & 0 & 2 & 2 & 4 \\
\hline & & $\%$ compris dans SEXE & $0,0 \%$ & $6,2 \%$ & $8,0 \%$ & $6,9 \%$ \\
\hline & \multirow{2}{*}{ Total } & Effectif & 1 & 32 & 25 & 58 \\
\hline & & $\%$ compris dans SEXE & $100,0 \%$ & $100,0 \%$ & $100,0 \%$ & $100,0 \%$ \\
\hline
\end{tabular}

logiciel SPSS 20 
After the analysis in Table 9, the results reveal that $6.2 \%$ of surveys are men versus $20 \%$ of women. These are agents who have a primary level of education. In reality we can say that there is more woman having primary education in this agricultural activity among the households.

It follows that at the secondary level we have $34.4 \%$ of men against $40 \%$ of women.

Finally, at the university or higher education level, men achieve 46\%, compared with $28 \%$ of women. This situation can be explained by the fact that a large number of women do not have access to university because of several reasons such as : early marriage, chiefs and customs, poverty, parents, environment, etc.

From the foregoing, we are witnessing an imbalance of "gender" in decision-making at the management of income-generating activities at the UPN peripheral area because women do not have the required qualifications, unlike to men. As strategies, it is useful to encourage women to pursue graduate and university studies at the hinterlands (Ngomba kinkusa) of Kinshasa.

By applying the chi-2 test, we seek to understand whether there is dependence between studies and gender in our study environment.

Table 10: Test of $\chi^{2}$ the link between level of education and sex

\begin{tabular}{|c|c|c|c|}
\hline & Tests du Khi-deux \\
\hline & Valeur & ddl & Signification asymptotique (bilatérale) \\
\hline Khi-deux de Pearson & $17,542^{\mathrm{a}}$ & 8 &, 025 \\
\hline Rapport de vraisemblance & 9,436 & 8 &, 307 \\
\hline Nombre d'observations valides & 58 & & \\
\hline a. 11 cellules (73,3\%) ont un effectif théorique inférieur à 5. L'effectif théorique minimum est de ,07. \\
\hline
\end{tabular}

Source: logiciel SPSS 20

The results of Table 10, show that the statistic is of the order of 17,542 with $\mathrm{P}$ value of 0,025 (ie less than 0,05 ) concretely, we can say that there is a dependence between the level of study and the sex. Moreover, the resemblance is not established between sex and level, since $\mathrm{P}$ value of 0.307 is strictly greater than 0.05 .

\section{Conclusion}

We conducted a scientific study in Kinshasa and its hinterlands (UPN) to know the effects of the consumption of imported food products (cereals, fresh foods) in the capital. The various results obtained have shown that the DRC is among the least developed countries despite the macroeconomic progress it has made since 2002. More than half of its population is still affected by poverty despite the fact that implementation of the Millennium Development Goals (MDGs).

We found that $55.2 \%$ of respondents are male, $43.1 \%$ are female and $1.7 \%$ are respondents who did not answer the question.

The study reveals that among the respondents, $43.1 \%$ are based solely on price; $39.7 \%$ have the criterion that products are nutritious, $12 \%$ are based on the fact that products are good for health and balanced, 5.2\% are based on freshness; 3.4\%, on packaging and good preservation of products. 
However, all these products are in competition with local production, which in our opinion is insufficient to meet the demand of Kinois consumers. Thus, the periphery of the city of Kinshasa, practices certain agricultural activities without the support of the Government to optimize their profitability.

Only the price remains a dominant factor in this market. The provenance and quality of the product are of the least concern to Kinshasa consumers. This situation justifies how the population consumes more of the products coming from the outside because of the cheaper price rather than those produced locally which would cost a little more expensive, but of good quality.

The results related to maize consumption, show that $69 \%$ of respondents did not comment; $25.9 \%$ say they consume local corn and 5.1\% consume imported maize.

Unlike rice, the population of Kinshasa UPN and the hinterlands prefer to consume more local corn than imported. This can be justified by several reasons: the taste, flavor, the price, and the good quality of the grains. On the subject of consumer income, we have seen that $65.5 \%$ of respondents derive their income from small businesses; $12.1 \%$ are civil servants of the State; $3.4 \%$ derive their income from craft activities and 1.7\% from agricultural activities.

Indeed, agricultural activities in Kinshasa, are not a priority as demonstrated by the results obtained $(1.7 \%)$. And the power in place can not put the consistent means to fight against this food addiction.

This situation exposes the country (and more particularly the kinois) to be dependent on the outside world with regard to their consumption of basic foodstuff. It is time for this to change to one day build a sustainable economy and ensure food security. These foods cause certain diseases in the community because of unsatisfied hygienic conditions, exceeding the date of consumption, poor quality .... Hence control is essential to protect consumers.

To ensure sustainable development, it is important for the DRC to invest in the agricultural sector such as peri-urban agriculture in Kinshasa. This can contribute to economic growth and reduce poverty. that access to credit by local producers is among the avenues for solution or strategy in this area that makes food available to the local population.

\section{References}

Bruno A. 1973 : " Les méthodes en sciences sociales », éd. Mont Chrétien, Paris,

Bublot G, 1974 : écnnomie de la production agricole, éd Vander Paris

Genereux J., 2004 : économie politique 2 microéconomies, 4ème éd. hachette

Girdd-Gret, 2006 : Memento de l'agronomie

Grawitz, D. 2011 : « Méthodes des sciences sociales », 8ème édition, Dalloz, Paris, 1972,

Idwight.H. Perkins, Steven, R et David, 2006 : économie de développement», 3é édition de Boeck, Belgique.

Kasongo Numbi, 2008 : «l'Afrique se recolonise », Harmattan, Paris, Cirad-Gret.

Maximy R, 1984 : Kinshasa ville en suspens, Dynamique de la croissance et problèmes d'urbanisme, approche socio politique, Paris

Minplan, 2017 : Document de Stratégies de Croissance et Réduction de la Pauvreté ; ministère de plan, RDC

Van Vracem. P et Martine Janssens-umflat, M, 1994 : comportement du consommateur, facteur d'influence externe famille, groupe, culture, éco et entreprise, éd, de Boeck

Yves Dupré J et Yrles S, 1991 : la crise agricole. Éd les études et documentation française 